\title{
Influence of melatonin on carbohydrate metabolism in the kidney of alloxan diabetic rats
}

\author{
O.Yu. Kushnir, I.M. Yaremii, V.I. Shvets, N.V. Shvets \\ Higher education institution in Ukraine «Bukovinian State Medical University», Chernivtsi; \\ e-mail:kushnir@bsmu.edu.ua
}

\begin{abstract}
The aim was to determine the influence of melatonin on basal levels of glucose $(B G)$, activities of glucose6-phosphate dehydrogenase (G6PD), pyruvate kinase (PK), glucose-6-phosphatase (G-6-Ph) and lactate dehydrogenase $(L D H)$ in the kidney of alloxan diabetic rats under conditions of different photoperiod. Alloxan diabetes was evoked via injecting the rats with a $5 \%$ solution of alloxan monohydrate intraperitoneally in a dose of $170 \mathrm{mg} / \mathrm{kg}$ of body weight. Three groups of animals were kept in conditions of artificial equinox, constant darkness and constant light respectively during 7 days. In each group there were subgroups collected for control, rats with diabetes mellitus $(D M)-B G \geq 8.0 \mathrm{mmol} / \mathrm{l}$, rats with impaired glucose tolerance $(I G T)-B G \leq 6.9 \mathrm{mmol} / \mathrm{l}$ and $D M$ and IGT rats which respectively received melatonin in a dose of $10 \mathrm{mg} /$ $\mathrm{kg}$ of body weight. Alloxan monohydrate administration results in a significant elevation of the activities of G-6-Ph by $147 \%$ and $L D H$ by $39 \%$, however a decrease of G6PD by $48 \%$ and PK by $67 \%$ were in a direct dependence by the presence of hyperglycemia. The established changes of the indices turned out to be more marked under the conditions of constant light. Introduction of melatonin led to improvement of the carbohydrate metabolism.
\end{abstract}

Key words: melatonin; alloxan diabetes; carbohydrate metabolism; kidney; rats.

\section{INTRODUCTION}

Diabetes is a condition developing due to the deterioration of the carbohydrate, fat and protein metabolisms resulting from the lack of the insulin secretion or decreased sensitivity of tissues to insulin. The deterioration in the antioxidant system also has a part in the decline in the clinic state of the patient. In diabetics, the fasting blood glucose, the plasma LDL (LowDensity Lipoprotein) and the free fatty acid levels increase remarkably [1]. Diabetes is a disease that affects millions of people of every sex and race effectively and globally every year. Diabetes is a disease which disturbs the glycemic control and the antioxidant metabolism disorder plays a role in the development of the clinic state.

Diabetes mellitus can damage eyes, kidneys, nerves and heart. Microvascular and macrovascular disorders are the leading causes of morbidity and mortality in diabetic patients (C) O.Yu. Kushnir, I.M. Yaremii, V.I. Shvets, N.V. Shvets
[2]. Hyperglycemia can increase the indicators of lipid peroxidation and oxidative stress in which free radicals fulfill the main role in the pathogenesis of these complications. Therefore, antioxidants which combat oxidative stress should be able to prevent and repair free radicals induced damages. Although free radicals contribute to kidney damage, atherosclerosis, diabetes, heart disease, nephrotoxicity and hepatotoxicity; however, clinical trials do not uniquely confirm a substantial impact on diabetic damage.

In the study [1], conventional experimental rat model was used with diabetes induced with streptozotocin (STZ) to evaluate effect of Viscum album on lipid peroxidation and antioxidant system. The comparison of the kidney malondialdehyde (MDA) values between the streptozotocin-induced rats (STZ) and control groups showed that the MDA level was significantly higher in the STZ group. When the kidney 
catalase activity is compared between the STZ and control groups, it was found to be lower in the STZ group. It was concluded, that oxidative stress is associated with diabetic complications.

Alloxan diabetes was reported to induce oxidative stress and generates reactive oxygen species (ROS). In the presence of intracellular thiols, especially glutathione, alloxan generates ROS in a cyclic redox reaction with its reduction product, dialuric acid. Autoxidation of dialuric acid generates superoxide radicals, hydrogen peroxide and, in a final iron-catalysed reaction step, hydroxyl radicals. These hydroxyl radicals are ultimately responsible for the death of the beta cells, which have a particularly low antioxidative defence capacity, and the ensuing state of insulin-dependent 'alloxan diabetes'.

Authors Mather A, Pollock C. take up the position that kidney contributes to glucose homeostasis through processes of gluconeogenesis, glucose filtration, glucose reabsorption, and glucose consumption. Under normal circumstances, up to $180 \mathrm{~g}$ /day of glucose is filtered by the renal glomerulus and virtually all of it is subsequently reabsorbed in the proximal convoluted tubule. This reabsorption is affected by two sodium-dependent glucose cotransporter (SGLT) proteins. Once glucose has been reabsorbed into the tubular epithelial cells, it diffuses into the interstitium across specific facilitative glucose transporters (GLUTs). GLUT1 and GLUT2 are associated with SGLT1 and SGLT2, respectively.

J. E. Gerich considered the precise regulation of plasma glucose concentrations is mainly determined by hormonal and neural factors, which regulate endogenous production of glucose. Acute glucoregulatory mechanisms involve insulin, glucagon and catecholamines, which can effect changes in plasma glucose levels over a matter of minutes. Insulin suppresses glucose release in both the liver and kidney by direct enzyme activation/deactivation, as well as by reducing the availability of gluconeogenic substrates and actions on gluconeogenic activators. Glucagon has no effect on the kidney, but increases both gluconeogenesis and glycogenolysis in the liver. Catecholamines have multiple acute actions, including stimulation of renal glucose release, inhibition of insulin secretion, stimulation of glucagon secretion, and increases in gluconeogenic substrate supply, stimulation of lipolysis and reduced tissue glucose uptake. In humans, only the liver and kidney contain significant amounts of the enzyme glucose-6-phosphatase and therefore are the only organs that are able to perform gluconeogenesis. Catecholamines normally exert a direct effect only on renal glucose release although they may indirectly affect both hepatic and renal glucose release by increasing availability of gluconeogenic substrates and by suppressing insulin secretion.

As a major hormone from the pineal gland, melatonin has been shown to play an important role in regulating the physiological and pathological functions of stem cells such as promoting proliferation, migration and differentiation [3]. Thus, melatonin combined with stem cell transplantation displayed promising application potential in neurodegenerative diseases, liver cirrhosis, wound healing, myocardial infarction, kidney ischemia injury, osteoporosis, etc. It exerts its physiological and pathological functions through its anti-oxidant, anti-inflammatory, anti-apoptosis and anti-ageing properties.

Melatonin (N-acetyl-5-methoxytryptamine) is the major product of the pineal gland, which functions as a regulator of sleep, circadian rhythm, and immune function. Melatonin and its metabolites have potent antioxidant/antiinflammatory properties, and they have proven to be highly effective in a variety of disorders linked to inflammation and oxidative stress [4]. Melatonin not only neutralizes reactive oxygen species (ROS), but also acts through the stimulation of several antioxidative enzymatic systems and stabilizing cell membranes. Therefore, ROS were shown to contribute to the cellular damage induced by ischemia-reperfusion.

Circadian disruption and obesity synergize to predispose to development of Type 2 diabetes (T2DM), signifying that therapeutic targeting 
of both circadian and metabolic dysfunctions should be considered as a potential treatment approach [5].

The influence of melatonin on carbohydrate metabolism in kidney of alloxan-induced diabetic rats on the background of different photoperiod is poorly understood.

The present study evaluated whether melatonin administration would have photoperioddependent protective effect against kidney alloxan-induced changes in carbohydrate metabolism.

The aim was to determine the influence of melatonin on basal levels of glucose (BG), activities of glucose-6-phosphate dehydrogenase (G6PD, EC 1.1.1.49), pyruvate kinase (PK, EC 2.7.1.40), glucose-6-phosphatase (G-6-Ph, EC 3.1.3.9) and lactate dehydrogenase (LDH, EC 1.1.1.27) in the kidney of alloxan diabetic rats under conditions of varying length of the light period.

\section{METHODS}

The research was performed in compliance with the Rules of the work using experimental animals (1977) and the Council of Europe Convention on the Protection of Vertebrate Animals used in experiments and other scientific purposes (Strasbourg, 1986), according to directions of International Committee of Medical Journals Editors (ICMJE), as well as "Bioethical expertise of preclinical and other scientific researches conducted on animals" (Kyiv, 2006). The experiments were carried out on 162 sexually mature male albino rats with the body mass $-(0.18-0.20) \mathrm{kg}$. Alloxan diabetes was evoked via injecting the rats with a $5 \%$ solution of alloxan monohydrate intraperitoneally in a dose of $170 \mathrm{mg} / \mathrm{kg}$ of body weight [6]. In the simulation, artificial equinox (L:D=12:12), the animals were in vivarium conditions during 8 am $-8 \mathrm{pm}$ under incandescent daylight, and in the period from $8 \mathrm{pm}$ to $8 \mathrm{am}$ in total darkness. In the simulation, dark deprivation (L:D = 0:24) during the feeding of animals and during manipulation using a weak red light intensity $2 \mathrm{Lx}$ for 10 minutes a day. Simulation conditions of constant illumination takes place using fluorescent light intensity of $500 \mathrm{~lx}$ at the level of the bottom of the cell [7].

The animals were divided into 3 groups: 1 ) rats that were under artificial equinox (Light: Darkness $=12 \mathrm{pm}: 12 \mathrm{am}(\mathrm{LD})$ ); 2) rats that were under conditions of constant darkness (L: D = 12 am: $12 \mathrm{pm}(\mathrm{DD})$ ); 3) rats that were under conditions of constant light (L:D = 12:12 $(L L)$ ). In each group there were 5 subgroups 1) control group; 2) alloxan diabetic rats with diabetes mellitus (BG $\geq 8.0 \mathrm{mmol} / \mathrm{l})(\mathrm{DM}) ; 2)$ DM rats which were introduced the melatonin ("Sigma", USA) preparation intraperitoneally in a dose of $10 \mathrm{mg} / \mathrm{kg}$ of body weight at $8^{00}$ daily during 7 days starting with a 5 -th 24 hour period after the injection of alloxan; 3 ) alloxan diabetic rats with latent diabetes $(\mathrm{BG} \leq 6.9$ $\mathrm{mmol} / \mathrm{l}$ ) which had impaired glucose tolerance (IGT); 5) IGT rats which were introduced the melatonin ("Sigma", USA) same way. Blood was taken from the tail vein to evaluate the BG level with the use of OneTouchUltra (LifeScan, USA). Rats were sacrificed on the twelfth day from the beginning of the experiment in accordance with the ethical treatment of animals. The kidney tissue was quickly removed, rinsed in saline, blotted, weighed and homogenized. The homogenate, $5 \%$ in ice-cold $0.25 \mathrm{mM}$ tris-HClbuffer ( $\mathrm{pH}$ 7.4), was made using a homogenizer. The supernatant of the homogenate, prepared by ultracentrifugation for $10 \mathrm{~min}$ at $3000 \mathrm{~g} / \mathrm{min}$ was used for measurement of activities of enzymes. Determinations of the enzymes activities were carried out by standard methods [8]. Statistical analysis was performed using Statistica 10 StatSoft Inc. To determine an adequate method of statistical estimation of the average difference between the study groups preliminary check of quantities distribution in samples was held. According to the criteria Shapiro-Wilk, which is used to assess the normality of distribution in the sample volume $n \leq 50$, all samples not received data on deviation of the distribution of samples from normal $(p>0.05)$. Given these data, the use 
of Mann-Whitney test was considered sufficient for valid conclusions. Differences were considered to be statistically significant at $p \leq 0.05$.

\section{RESULTS AND DISCUSSION}

Insertion of melatonin for 7 days helped to reduce basal glucose level (Fig. 1) in the group of animals with overt diabetes, indicating its hypoglycemic action, what was less pronounced in LL conditions.

The prevalence of diabetes has exponentially increased in recent decades due to environmental factors such as nocturnal lifestyle and aging, both of which influence the amount of melatonin produced in the pineal gland [9]. It may be that lack of melatonin can cause impairment in glucose utilization. It was detected, that melatonin stimulates glucose transport to skeletal muscle cells via insulin receptor substrate-1 / phosphoinositide 3-kinase (IRS-1/PI-3-kinase) pathway, which implies, at the molecular level, its role in glucose homeostasis and possibly in diabetes. Additionally, exposure to light at night and aging, both of which lower endogenous melatonin levels may contribute to the incidence and/or development of diabetes [10].

Possible link between melatonin and insulin interaction may be in its protective effect against free radical attack of $\beta$-cells Langergans islets in pancreas. In witness of this fact we did the investigations of Langergans islets in our previous studies [11]. Histomorphological alterations in Langergans islets of pancreas in diabetic rats were recorded: their share reliably decreased by $55 \%$, numbers of beta-cells decreased by $90 \%$, percentage of beta-cells with necrosis was $97 \%$ respectively compared with the indices of control animals. Melatonin treatment caused a sharp decrease in the elevated serum glucose and partial regeneration/proliferation of beta-cells of islets. It is concluded that the hypoglycemic action of melatonin could be partly due to amelioration in the beta-cells of pancreatic islets.

Probable reduction of melatonin synthesis and secretion under conditions of constant illumination coupled with reduced sensitivity to insulin, reduces the activities (Fig.2 a, b) of G6PD and PK in rats with diabetes mellitus which is mostly common in LL conditions.

In groups of DM rats the activities of G6PD and PK were decreased: by $48 \%$ and $67 \%$

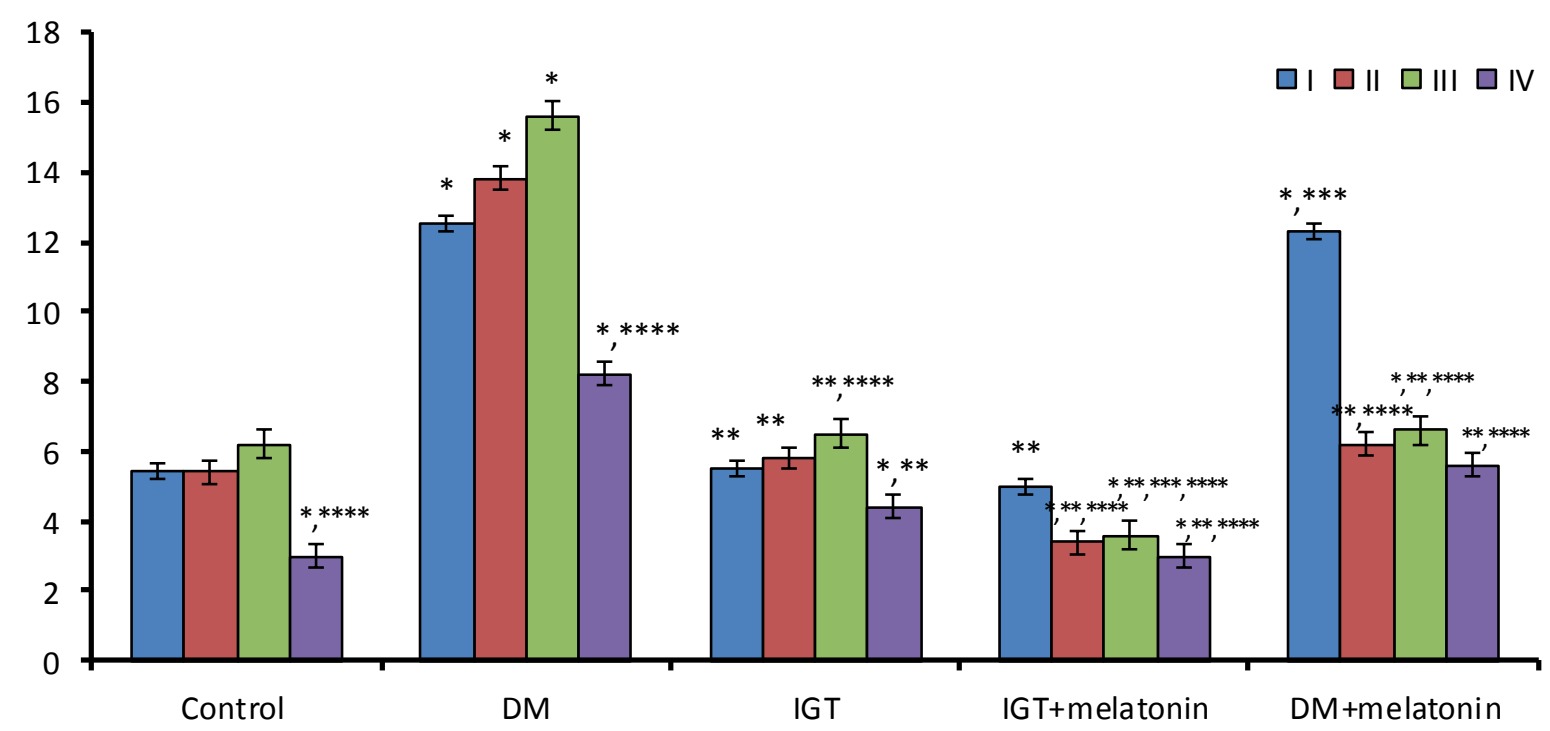

Fig. 1.The level of basal glycemia $(\mathrm{mmol} / \mathrm{l})$ in blood of rats $(\mathrm{n}=6, \mathrm{x} \pm \mathrm{S} \overline{\mathrm{x}}): 1 . *, * *, * * *, * * * *$ changes are reliable $(\mathrm{p} \leq 0.05) .2$. * - concerning rats in LD on 12-th day; ** - concerning rats with diabetes mellitus (DM); *** - concerning rats with impaired glucose tolerance (IGT); **** - concerning indices on 4-th day in same illumination. I - artificial equinox (LD) on 4-th day; II - artificial equinox (LD) on 12-th day; III - constant light (LL) on 12-th day; IV - constant darkness (DD) on 12-th day 

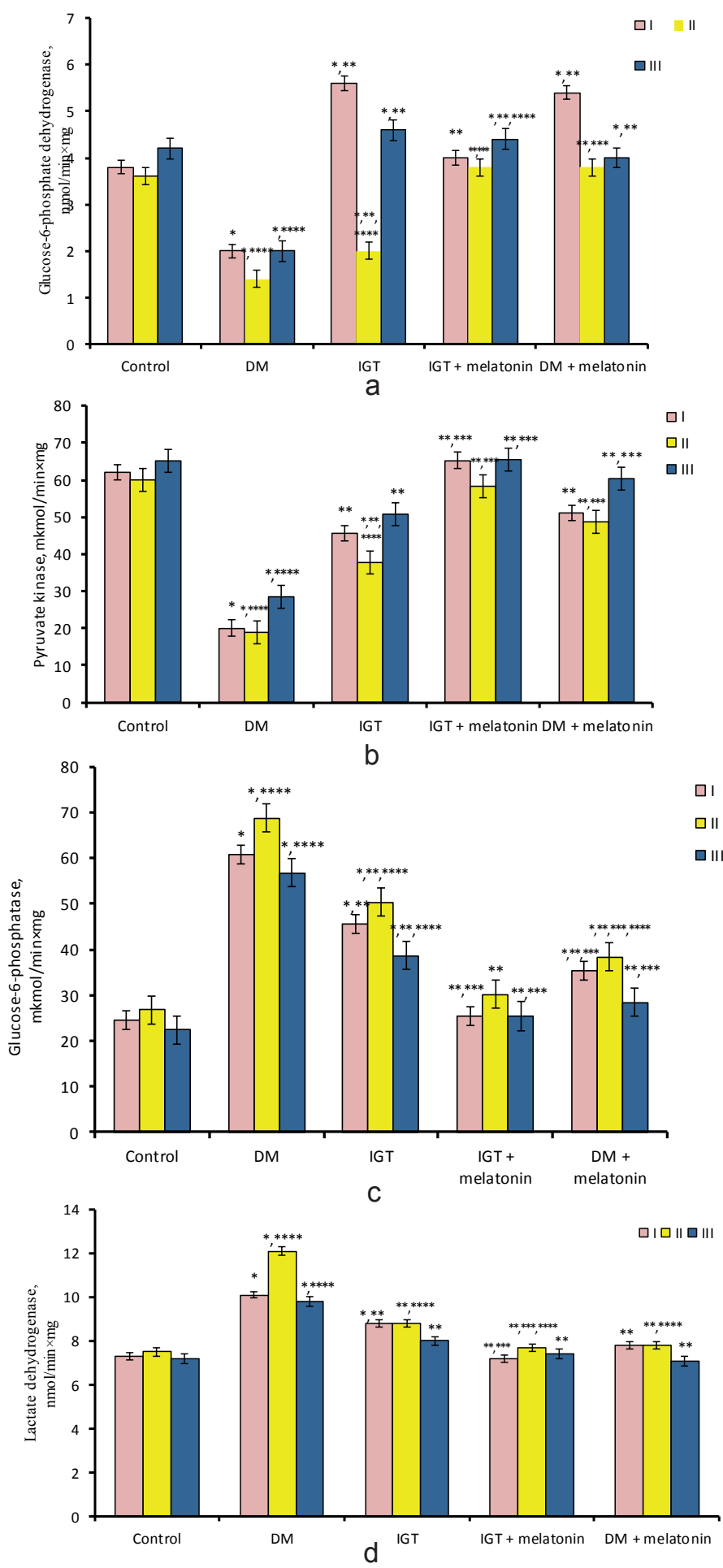

Fig.2. Effect of melatonin in a dose $10 \mathrm{mg} / \mathrm{kg}$ on activities of certain enzymes in kidney under conditions of varying length of the light period $(\mathrm{n}=6, \mathrm{x} \pm \mathrm{S} \overline{\mathrm{x}}): 1 . *, * *, * *, * * * *$ - changes are reliable $(\mathrm{p} \leq 0.05) .2 . *$ - concerning control rats of same group; ** - concerning rats with DM of same group; ${ }^{* * *}$ - concerning rats with IGT of same group; ${ }^{* * * *}$ - concerning the values of control animals in the conditions of natural (artificial) equinox. I - artificial equinox (LD); II - constant darkness (DD); III constant light (LL) 
$(\mathrm{P}=0.0031 ; \mathrm{P}=0.00024)$ in $\mathrm{LD}$; by $62 \%$ and $70 \%$ $(\mathrm{P}=0.0002 ; \mathrm{P}=0.00017)$ in $\mathrm{LL} ;$ by $48 \%$ and $54 \%$ $(\mathrm{P}=0.00071 ; \mathrm{P}=0.00057)$ in $\mathrm{DD}$ conditions respectively compared with control under LD conditions. Under constant illumination conditions in LL there was no typical increase in activity of G6PD in the group of animals with IGT, but rather there was a decline by $63 \%(\mathrm{P}=0.00038)$ of this indicator compared with those of control rats, provided equinox. It is well known [7] that pinealectomy, same as its hypofunction used by permanent lighting, leads to decreased synthesis and secretion of melatonin, which causes insulin resistance and reduces the gene expression of glucose transporter GLUT 4, 2, 1. It is logical that the activities of G6PD and PK are reduced under conditions of constant illumination during diabetes mellitus, whether an administration of melatonin leads to increase its activity. Secondary, the influence of melatonin increased activity of G6PD in the kidney of diabetic rats may occur due to the increasing number of substrate for G6PD (stimulating the flow of glucose into cells and its phosphorylation) and direct action [9]. Melatonin also may increase the plasma concentration of leptin. Findings [12] suggest that leptin reverses the catabolic consequences of total lack of insulin, potentially by suppressing glucagon action on liver and enhancing the insulinomimetic actions of IGF-1 on skeletal muscle, and suggests strategies for making type 1 diabetes insulin-independent.

In group of rats with IGT the activity of G6PD rise up by $47 \%(\mathrm{P}=0.0011)$ in $\mathrm{LD}$ and $20 \%(P=0.013)$ in $\mathrm{DD}$ compared with control value in $\mathrm{LD}$ conditions. Increase of G6PD activity in condition of DM with preserved normoglycemia (IGT) is probably a compensatory reaction aimed at reducing of $\mathrm{ROS}$. $\mathrm{NADPH}_{2}$ reducing equivalents (that are produced in this reaction) are used for regeneration of glutathione from its oxidized form due to action of $\mathrm{NADPH}_{2}$-dependent glutathione reductase. Glutathione neutralizes ROS, both directly and through glutathione peroxidase. Known are the check studies results that suggest an increased regenerative or recovery process in the rat pancreatic islets and an increased hepatic antioxidant defenses in the group of alloxan-resistant rats. In hyperglycemia a reduction of the antioxidant power and an increased production of nitric oxide (NO) have been reported [13].

It is well known [14], pinealectomy leads to decreasing of reduced glutathione (GSH) level and increasing of malonic aldehyde in comparison to control under equinox. Moreover, an increasing of G6PD activity caused by melatonin [15] is useful for reduction of glutathione. In recent study [16] melatonin in combination with sodium nitroprusside (SNP) increased GSH levels in all organs, as compared to the administration of SNP alone; this effect was observed after 3,6 and $24 \mathrm{~h}$. The activity of superoxide dismutase (SOD), catalase and glutathione peroxidase (GSH-Px) in the melatonin-treated group increased after $3 \mathrm{~h}$ in all the organs, while in liver and kidney the increase was also observed after 6 h. Conversely, the SNP intoxication caused a decrease of the activity of enzymes in the tested organs in all intervals, while administration of melatonin + SNP resulted in increased activities of SOD, catalase and GSH-Px in all the organs after $3 \mathrm{~h}$ and $6 \mathrm{~h}$.

In accordance with results obtained in diabetic rats (Fig. 2 c, d) the activities of G-6-Ph and LDH were increased: by $147 \%$ and $39 \%$ $(\mathrm{P}=0.00049 ; \mathrm{P}=0.0029)$ in $\mathrm{LD} ;$ by $180 \%$ and $67 \%(\mathrm{P}=0.00039 ; \mathrm{P}=0.0024)$ in $\mathrm{LL} ;$ and by $130 \%$ and $34 \%(\mathrm{P}=0.0013 ; \mathrm{P}=0.012)$ in $\mathrm{DD}$ respectively compared with control under LD conditions. Melatonin resulted in decrease of G-6-Ph activity by $42 \%(\mathrm{P}=0.0022)$ in $\mathrm{LD}$, by $44 \%(\mathrm{P}=0.0019)$ in $\mathrm{LL}$ and normalization in DD respectively compared with control value in LD conditions. Melatonin caused normalization of LDH activity in rats with DM on the background of all conditions compared with control in LD conditions.

In group of rats with IGT (Fig. $2 \mathrm{c}, \mathrm{d})$ the activities of G-6-Ph and $\mathrm{LDH}$ were increased by $85 \%(P=0.0016)$ and $20 \%(P=0.013)$ in $L D$; 
by $105 \%(\mathrm{P}=0.0014)$ and by $21 \%(\mathrm{P}=0.047)$ in LL; the activity of G-6-Ph was higher by $57 \%$ $(\mathrm{P}=0.011)$ in $\mathrm{DD}$ respectively compared with control value in LD conditions. Melatonin led to normalization of mentioned indexes in group of rats with IGT in all conditions.

Reduced activity of G-6-Ph in alloxan diabetic rats under melatonin action, demonstrated by our results, is probably due to the fact that melatonin is in the physiological counteraction with cortisone. Increased concentration of corticosterone and 11-dehydrocorticosterone was found [17] in the serum of rats with alloxan diabetes. Melatonin at a dose of $4 \mathrm{mg} / \mathrm{kg}$ inhibited pyridoxal-induced glycogenolysis and reduced hyperglycemia due to reduced levels of catecholamines in blood plasma [18].

Our results demonstrate the increase in the activity of LDH in diabetic rats. We have reached the recovery of the PK activity and normalization of LDH activity in the kidney of rats by melatonin injections. It was [19] reported that melatonin modifies carbohydrate and lipid utilization in exercised rats, maintaining glycemia and reducing plasma and liver lactate and plasma beta-hydroxybutyrate. This proves of melatonin restoring the aerobic glucose oxidation process and reducing of ketoacidosis [19].

Thus, according to the results we've got, melatonin shows its protective action against hyperglycemia. The level of basal glycemia in diabetic rats was decreased by melatonin action in all types of photoperiod. Process of gluconeogenesis was reduced by melatonin because the activity of glucose-6-phosphatase diminished in diabetic rats. The activities of glucose6-phosphate dehydrogenase and pyruvate kinase in diabetic rats were increased under its action in all conditions. It means that melatonin probably increases use of glucose for regeneration of $\mathrm{NADPH}_{2}$ and aerobic oxidation of glucose that indicate an acceleration of antioxidative protection and energy production in kidney of diabetic rats. We found that melatonin may prevent ketoacidosis by decreasing the activity of lactate dehydrogenase in kidney of alloxan diabetic rats. Such positive changes in carbohydrate metabolism were more pronounced under conditions of dark illumination.

The work is a product of the intellectual environment of the authors; all members have contributed in various degrees to the analytical methods used, to the research concept, and to the experiment design.

\section{О.Ю. Кушнір, І.М. Яремій, В.І. Швець, Н.В. Швець}

\section{ВПЛИВ МЕЛАТОНІНУ НА ВУГЛЕВОДНИЙ ОБМІН У НИРКАХ ЩУРІВ 3 АЛОКСАНОВИМ ДІАБЕТОМ}

Досліджували вплив мелатоніну на рівень базальної глікемії, активність глюкозо-6-фосфатдегідрогенази (ГбФД), піруваткінази (ПК), глюкозо-6-фосфатази (Г-6-Ф) і лактатдегідрогенази (ЛДГ) у нирках щурів $з$ алоксановим діабетом в умовах різної довжини світлового періоду. Діабет моделювали за допомогою ін'єкції щурам 5\%-го розчину моногідрату алоксану внутрішньоочеревинно в дозі 170 мг/кг. Три групи тварин утримували в умовах штучного рівнодення, постійної темряви і постійному світлі впродовж 7 діб. У кожній групі було виділено підгрупи: контрольну, щурів із діабетичним статусом, порушеною толерантністю до глюкози, а також відповідні групи тварин, яким вводили мелатонін в дозі 10 мг/кг. Уведення моногідрату алоксану призводило до зростання активності Г-6-Ф на $147 \%$ і ЛДГ на 39\%, проте зменшення активності Г6ФД на 48\% і ПК на 67\% перебувало в прямій залежності від наявності гіперглікемії. Встановлені зміни показників виявилися більш помітними в умовах постійного освітлення. Введення мелатоніну спричинювало поліпшення вуглеводного обміну.

Ключові слова: мелатонін; алоксановий діабет; обмін вуглеводів; нирки; щури.

Вищий державний навчальний заклад Украӥни «Буковинський державний медичний університет», Чернівиі; e-mail:kushnir@bsmu.edu.ua

\section{О.Ю. Кушнир, И.Н. Яремий, В.И. Швец, Н.В. Швец}

\section{ВЛИЯНИЕ МЕЛАТОНИНА НА УГЛЕВОДНЫЙ ОБМЕН В ПОЧКАХ КРЫС С АЛЛОКСАНОВЫМ ДИАБЕТОМ}

Цель настоящего исследования состояла в том, чтобы определить влияние мелатонина на уровень базальной гликемии, активность глюкозо-6-фосфатдегидрогеназы (ГбФД), пируваткиназы (ПК), глюкозо-6-фосфатазы (Г6-Ф) и лактатдегидрогеназы (ЛДГ) в почках крыс с аллок- 
сановым диабетом в условиях различной длины светового периода. Диабет моделировали с помощью инъекции 5\%-го раствора моногидрата аллоксана внутрибрюшинно в дозе 170 мг/кг. Три группы животных содержали в условиях искусственного равноденствия, постоянной темноты и постоянного освещения в течение 7 сут. В каждой группе выделяли подгруппы контрольных крыс с диабетическим статусом и нарушенной толерантностью к глюкозе, а также соответственные группы животных, которым вводили мелатонин в дозе 10 мг/кг. Введение моногидрата аллоксана значительно увеличивало активност Г-6-Ф на 147\% и ЛДГ на $39 \%$, тогда как уменьшение активности Г6ФД на 48\% и ПК на $67 \%$ находились в прямой зависимости от наличия гипергликемии. Установленные изменения показателей оказались более заметными в условиях постоянного освещения. Введение мелатонина привело к улучшению состояния углеводного обмена.

Ключевые слова: мелатонин; аллоксановый диабет; углеводный обмен; почки; крысы.

\section{REFERENCES}

1. Turkkan A, Savas HB, Yavuz B, Yigit A, Uz E, Bayram NA, Kale B. The prophylactic effect of Viscum album in streptozotocin-induced diabetic rats. North Clin Istanb. 2016; 3(2):83-9. doi: 10.14744/nci.2016.22932.

2. Rahimi-Madiseh M, Malekpour-Tehrani A, Bahmani M, Rafieian-Kopaei M. The research and development on the antioxidants in prevention of diabetic complications. Asian Pac J Trop Med. 2016; 9(9):825-31. doi: 10.1016/j. apjtm.2016.07.001.

3. Shuo Z, Chen S, Yuan L, Liu Y. Melatonin as a promising agent of regulating stem cell biology and its application in disease therapy. Pharmacol Res. 2016; pii: S10436618(16)31133-1. doi: 10.1016/j.phrs.2016.12.035.

4. Carrillo-Vico A, Guerrero JM, Lardone PJ, Reiter RJ. A review of the multiple actions of melatonin on the immune system. Endocrine. 2005; 27(2):189-200. doi: 10.1385/ ENDO:27:2:189.

5. Thomas AP, Hoang J, Vongbunyong K, Nguyen A, Rakshit K, Matveyenko AV. Administration of melatonin and metformin prevents deleterious effects of circadian disruption and obesity in male rats. Endocrinology. 2016:en20161309.

6. Lenzen S. The mechanisms of alloxan- and streptozotocininduced diabetes. Diabetologia. 2008; 51(2):216-26.

7. Tanedja K., Yaremii I., Kushnir O. Protective effects of melatonin in alloxan diabetic rats under conditions of constant darkness. 24-th European Students' Conference ["Exploring the unknown"]. 2013; ESCID 396.

8. Singh J, Kakkar P. Antihyperglycemic and antioxidant effect of Berberis aristata root extract and its role in regulating carbohydrate metabolism in diabetic rats. J Ethnopharmacol. 2009; 123(1):22-6. doi: 10.1016/j. jep.2009.02.038.

9. Ha E, Yim SV, Chung JH, Yoon KS, Kang I, Cho YH, Baik HH. Melatonin stimulates glucose transport via insulin receptor substrate-1/phosphatidylinositol 3-kinase pathway in $\mathrm{C} 2 \mathrm{C} 12$ murine skeletal muscle cells. J Pineal Res. 2006; 41(1):67-72.

10. Lin GJ, Huang SH, Chen YW, Hueng DY, Chien MW, Chia WT, Chang DM, Sytwu HK. Melatonin prolongs islet graft survival in diabetic NOD mice. J Pineal Res. 2009; 47(3):284-92. doi: 10.1111/j.1600-079X.2009.00712.x.

11. Kushnir A, Davydenko I. Influence of melatonin on condition of the langergans isles of the pancreas in alloxan diabetic rats. World of Medicine and Biology. 2009; 5(4):31-5.

12. Yu X, Park BH, Wang MY, Wang ZV, Unger RH. Making insulin-deficient type 1 diabetic rodents thrive without insulin. The Proceedings of the National Academy of Sciences USA. 2008; 105(37):14070-14075. doi: 10.1073/ pnas.0806993105.

13. Gumieniczek A, Wilk M. Nitrosative stress and glutathione redox system in four different tissues of alloxan-induced hyperglycemic animals. Toxicol Mech Methods. 2009; 19(4):302-7. doi: 10.1080/15376510902839762

14. Sahna E, Parlakpinar H, Vardi N, Ciğremis Y, Acet A. Efficacy of melatonin as protectant against oxidative stress and structural changes in liver tissue in pinealectomized rats. Acta Histochem. 2004; 106(5):331-6.

15. Gerush I., Boichuk T., Yaremii I., Kushnir O., Gerush O. Effects of melatonin on the glutathione system in the blood of alloxan diabetic rats. The International Union of Biochemistry and Molecular Biology (IUBMB) and The Federation of European Biochemical Societies (FEBS). 2012;279(1):88.

16. Goc Z, Szaroma W, Kapusta E, Dziubek K. Protective effects of melatonin on the activity of SOD, CAT, GSH-Px and GSH content in organs of mice after administration of SNP. Chin J Physiol. 2017; 60(1). pii: CJP.2017.BAF435. doi: 10.4077/CJP.2017.BAF435.

17. Selyatitskaya VG, Cherkasova OP, Pankina TV, Palchikova NA. Functional state of adrenocortical system in rats with manifest alloxan-induced diabetes mellitus. Bull Exp Biol Med. 2008; 146(6):708-10.

18. Budhram R, Lau-Cam CA. Attenuating effect of melatonin on pyridoxal-stimulated release of adrenomedullary catecholamines in the rat. Life Sciences. 2009. Life Sci. 2009; 84(19-20):696-704. doi: 10.1016/j.1fs.2009.02.017.

19. Sánchez-Campos S, Arévalo M, Mesonero MJ, Esteller A, González-Gallego J, Collado PS. Effects of melatonin on fuel utilization in exercised rats: role of nitric oxide and growth hormone. J Pineal Res. 2001; 31(2):159-66. 